\title{
Structure-guided protein engineering increases enzymatic activities of the SGNH family esterases
}

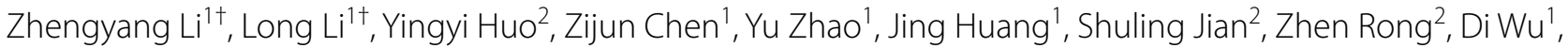

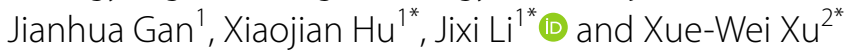

\begin{abstract}
Background: Esterases and lipases hydrolyze short-chain esters and long-chain triglycerides, respectively, and therefore play essential roles in the synthesis and decomposition of ester bonds in the pharmaceutical and food industries. Many SGNH family esterases share high similarity in sequences. However, they have distinct enzymatic activities toward the same substrates. Due to a lack of structural information, the detailed catalytic mechanisms of these esterases remain barely investigated.

Results: In this study, we identified two SGNH family esterases, CrmE10 and AlinE4, from marine bacteria with significantly different preferences for $\mathrm{pH}$, temperature, metal ion, and organic solvent tolerance despite high sequence similarity. The crystal structures of these two esterases, including wild type and mutants, were determined to high resolutions ranging from $1.18 \AA$ to $2.24 \AA$. Both $C r m E 10$ and AlinE4 were composed of five $\beta$-strands and nine a-helices, which formed one compact $\mathrm{N}$-terminal $\alpha / \beta$ globular domain and one extended $\mathrm{C}$-terminal domain. The aspartic residues (D178 in CrmE10/D162 in AlinE4) destabilized the conformations of the catalytic triad (Ser-Asp-His) in both esterases, and the metal ion $\mathrm{Cd}^{2+}$ might reduce enzymatic activity by blocking proton transfer or substrate binding. CrmE10 and AlinE4 showed distinctly different electrostatic surface potentials, despite the similar atomic architectures and a similar swap catalytic mechanism. When five negatively charged residues (Asp or Glu) were mutated to residue Lys, CrmE10 obtained elevated alkaline adaptability and significantly increased the enzymatic activity from 0 to $20 \%$ at pH 10.5. Also, CrmE10 mutants exhibited dramatic change for enzymatic properties when compared with the wide-type enzyme.
\end{abstract}

Conclusions: These findings offer a perspective for understanding the catalytic mechanism of different esterases and might facilitate the industrial biocatalytic applications.

Keywords: Esterase, SGNH superfamily, Swapped structure, Alkaline adaptability

\footnotetext{
*Correspondence: xjhu@fudan.edu.cn; lijixi@fudan.edu.cn; xuxw@sio.org.cn

${ }^{\dagger}$ Zhengyang Li and Long Li contributed equally to this study

1 State Key Laboratory of Genetic Engineering, School of Life Sciences,

MOE Engineering Research Center of Gene Technology, Shanghai

Engineering Research Center of Industrial Microorganisms, Fudan University, Shanghai 200438, China

${ }^{2}$ Key Laboratory of Marine Ecosystem Dynamics, Ministry of Natural Resources, Ministry of Natural Resources \& Second Institute of Oceanography, Hangzhou 310012, China
}

\begin{abstract}
Background
The SGNH-hydrolase family, a superfamily that includes the bacterial lipolytic enzyme GDSL family [1], consists of enzymes possessing four strictly conserved residues, Ser, Gly, Asn, and His, in four conserved blocks, I, II, III, and $V$, respectively $[2,3]$. Among these four residues, Ser and His serve as catalytic residues, and Ser, Gly, and Asn serve as oxyanion hole residues [2, 3]. The SGNHhydrolase family esterases have a consensus G-D-S-L
\end{abstract}


sequence motif different from the pentapeptide motif GXSXG in most of the other bacterial esterases, and they do not have the nucleophile elbow and cap-domain [4]. To date, only a few structural studies of bacterial SGNHhydrolase family esterases have been reported [2, 5-8]. Most of them have one molecule in an asymmetric unit characterized by a three-layered $\alpha / \beta / \alpha$-fold with a conserved core structure consisting of five $\beta$-strands and at least four $\alpha$-helices. The SGNH superfamily has conserved homologs ranging from prokaryotes to eukaryotes. Furthermore, due to the flexibility of its catalytic domain [9], the SGNH superfamily has multifunctional properties and broad specificities for substrates including carbohydrate esterase [10-12], lipase [13], protease [14], thioesterase [15, 16], arylesterase [15], lysophospholipase [17], and acyltransferase [13, 14]. The SGNH hydrolases from plants are involved in the regulation of development and morphogenesis [18, 19], defense [20], as well as tolerance to environmental stresses [21]. Besides, some SGNH hydrolases, like PlaA [22, 23] and PLB [24], play significant roles in the therapy of mammal diseases. Many SGNH family esterases share high sequence similarity but have distinctly different enzymatic activities toward the same substrates. Benefiting from the development of high-throughput sequencing technology, numerous SGNH hydrolases are found in the genomes of microorganisms, but the function and catalytic mechanism of microbial SGNH hydrolases remain unclear and need to be further explored.

The enzymes isolated from marine organisms usually have many specific features, including temperature adaption, alkaline adaption, salt tolerance, and metal tolerance, which might offer the potential for industrial application. Croceicoccus marinus $\mathrm{E} 4 \mathrm{~A} 9^{\mathrm{T}}$ was previously isolated from a deep-sea sediment sample [25], and Altererythrobacter indicus DSM $18604^{\mathrm{T}}$ was isolated from mangrove-associated wild rice [26]. Both strains belong to the Erytrobacteraceae family. According to in silico analysis of whole-genome sequences [27, 28], two novel SGNH-hydrolase family genes, crme10 and aline4, were screened from $C$. marinus and $A$. indicus, respectively. Here, we report the enzymatic characterizations and crystal structures of CrmE10 and AlinE4. These esterases exhibited similar atomic architectures and a similar swap catalytic mechanism; however, their electrostatic surface potentials and enzymatic properties were distinctly different. Structural comparison and structure-based protein engineering showed that mutants with five catalytic reaction-related residues could significantly change enzymatic features. These findings provide new insights into the catalytic mechanism of SGNH-hydrolase family enzymes and might benefit our understanding of their potential uses as biocatalysts.

\section{Results}

Identification and sequence analysis of CrmE10 and AlinE4

To compare the enzymatic activities of different esterases, the open reading frames of CrmE10 (Accession number: ARU15426.1) and AlinE4 (Accession number: WP_160739227) were identified from the wholegenomes of strains $C$. marinus $\mathrm{E} 4 \mathrm{~A} 9^{\mathrm{T}}$ and $A$. indicus DSM $18604^{\mathrm{T}}$, respectively. CrmE10 and AlinE4 have similar amino acid sequences (59.66\% identity, 85\% coverage). To reveal the relationship between CrmE10 and AlinE4, we performed a phylogenetic analysis with other known lipolytic enzymes using MEGA software [29]. The results showed that both CrmE10 and AlinE4 belong to the SGNH-hydrolase superfamily and the bacterial lipolytic enzyme GDSL family (Additional file 1: Fig. S1). The presence of strictly conserved Ser (residues Ser29 in CrmE10 and Ser13 in AlinE4), Gly (residues Gly66 in CrmE10 and Gly55 in AlinE4), Asn (residues Asn97 in CrmE10 and Asn81 in AlinE4), and His (residues His181 in CrmE10 and His165 in AlinE4) in blocks I, II, III, and $\mathrm{V}$, respectively, confirmed that these two enzymes were new members of the SGNH-hydrolase family [4] (Additional file 1: Fig. S2).

\section{Biochemical characterizations of CrmE10 and AlinE4}

To better understand the catalytic mechanism for CrmE10 and AlinE4, both enzymes were expressed and purified in Escherichia coli. CrmE10 exhibited the highest activity (approximately $29.4 \mathrm{U} / \mathrm{mg}$ ) toward $p$-nitrophenyl $\left(p\right.$-NP) hexanoate $(\mathrm{C} 6)$ at $\mathrm{pH} 7.5$ and $20{ }^{\circ} \mathrm{C}\left(K_{\mathrm{m}}, V_{\max }\right.$ and $k_{\text {cat }}$ of $0.16 \mathrm{mM}, 33.5 \mu \mathrm{mol} / \mathrm{mg} / \mathrm{min}$ and $29.4 \mathrm{~s}^{-1}$, respectively) (Fig. $1 \mathrm{a}-\mathrm{c}$ ). AlinE4 displayed the highest activity (approximately $25.8 \mathrm{U} / \mathrm{mg}$ ) toward $p$-NP butyrate (C4) at $\mathrm{pH} 7.5$ and $40{ }^{\circ} \mathrm{C}\left(K_{\mathrm{m}}, V_{\max }\right.$ and $k_{\text {cat }}$ of $0.10 \mathrm{mM}$, $26.9 \mu \mathrm{mol} / \mathrm{mg} / \mathrm{min}$ and $25.8 \mathrm{~s}^{-1}$, respectively) (Fig. 1a-c). CrmE10 had about $30 \%$ activity at $4{ }^{\circ} \mathrm{C}$ and showed no activity above $40{ }^{\circ} \mathrm{C}$, which indicated that CrmE10 was a cold-active enzyme. In contrast, AlinE4 was a mesophilic enzyme with over $32 \%$ activity above $60{ }^{\circ} \mathrm{C}$. Interestingly, AlinE4 showed a relatively high thermostability, evidenced by that the enzyme activity was hardly affected after heat treatment at $70{ }^{\circ} \mathrm{C}$ for $1 \mathrm{~h}$, and retained $20-40 \%$ activity after heat treatment at $100{ }^{\circ} \mathrm{C}$ for $1 \mathrm{~h}$ (Fig. 1d, e).

CrmE10 showed tolerance to low $\mathrm{NaCl}$ concentrations and retained over $83 \%$ and $41 \%$ of its initial activity at $1 \mathrm{M}$ and $2 \mathrm{M} \mathrm{NaCl}$, respectively (Fig. 1f). The activity of $\mathrm{CrmE10}$ was abolished when $\mathrm{NaCl}$ concentrations increased to $5 \mathrm{M}$. AlinE4 exhibited higher $\mathrm{NaCl}$ tolerance, retained over $61 \%$ activity at concentrations up to $5 \mathrm{M}$ (Fig. 1f). Metal ions $\mathrm{Ba}^{2+}, \mathrm{Ca}^{2+}, \mathrm{Mg}^{2+}$, and $\mathrm{Sr}^{2+}$ had minimal effects on the activities of the two enzymes (Fig. 1g). $\mathrm{Cd}^{2+}, \mathrm{Cu}^{2+}$, and $\mathrm{Mn}^{2+}$ completely abolished the enzymatic activity of CrmE10, but did not work for 
(See figure on next page.)

Fig. 1 Enzymatic characterizations of CrmE10 and AlinE4. a Enzymatic activities toward substrates with various chain lengths of $p$-nitrophenyl ( $p$-NP) esters. The value toward $p$-NP hexanoate and $p$-NP butyrate was 100\% for CrmE10 and AlinE4, respectively. $\mathbf{b}$ Effects of different pH on enzyme activities. Enzymatic activities were determined at a series of $\mathrm{pH}$. The value obtained at $\mathrm{pH} 7.5$ was taken as $100 \%$. The gap between different $\mathrm{pH}$ due to the buffer changing. $\mathbf{c}$ Effects of temperature on enzyme activities. Enzymatic activity was determined with a series of temperatures. The values obtained at $20^{\circ} \mathrm{C}$ and $40^{\circ} \mathrm{C}$ were taken as $100 \%$ for $\mathrm{CrmE} 10$ and AlinE4, respectively. $\mathbf{d}$ Effects of temperature on the stability of CrmE10 and AlinE4. The values obtained without heat treatment were taken as 100\%. e Effects of temperature on AlinE4 enzyme stability after incubation for different times. The values obtained without heat treatment were taken as $100 \%$. $\mathbf{f}$ Effects of $\mathrm{NaCl}$ concentration on the activities. The values obtained without $\mathrm{NaCl}$ in the reaction mixture were taken as $100 \%$. $\mathbf{g}$ Effects of different metal ions on the activities. The values obtained without ions in the reaction mixture were taken as $100 \%$. $\mathbf{h}$ Effects of organic solvents on the activities. The values obtained without organic solvent were taken as 100\%

AlinE4 as these metal ions retained over $20 \%, 5 \%$, and $70 \%$ activities, respectively (Fig. 1g). The addition of $\mathrm{Co}^{2+}, \mathrm{Ni}^{2+}$, and $\mathrm{Zn}^{2+}$ decreased the enzymatic activity of CrmE10 over $10 \%, 35 \%$, and $30 \%$, as well as for the activity of AlinE4 over 51\%, 85\%, and 79\%, respectively (Fig. 1g). The chelating agent EDTA did not decrease the activity of CrmE10 and AlinE4, which indicated that CrmE10 and AlinE4 were not metalloenzyme (Fig. 1g). Besides, compared with CrmE10, AlinE4 showed higher tolerance toward organic solvents, including acetone, ethanol, DMF, DMSO, glycerol, isopropanol, and methanol (15\%, v/v) (Fig. 1h).

\section{Overall structures of $\mathrm{CrmE} 10$ and AlinE4}

CrmE10 and AlinE4 were expressed in E. coli BL21 (DE3) cells as described previously [30]. They were further purified by metal ion affinity chromatography and gel-filtration, finally came out at peak positions of $15 \mathrm{ml}$ (CrmE10) on a Superdex 200 10/300 column and $74 \mathrm{ml}$ (AlinE4) on a Superdex $7516 / 600$ column, which corresponded to masses of around $22 \mathrm{kDa}$ and $23 \mathrm{kDa}$, respectively (Additional file 1: Fig. S3A and B). The theoretical molecular weights of CrmE10 and AlinE4 are $22.36 \mathrm{kDa}$ and $20.59 \mathrm{kDa}$, respectively. The multi-angle light scattering (MALS) results indicated that these two enzymes were monomeric in solution (Additional file 1: Fig. S3C and D).

To reveal the molecular basis of CrmE10 and AlinE4, we solved the crystal structures of the two proteins with high resolutions of $1.90 \AA$ for CrmE10 and $1.18 \AA$ for AlinE4, respectively (Additional file 1: Table S1). The CrmE10 structure was determined using the molecular replacement method with esterase TesA (PDB code: 4jgg) as an initial model. In the crystal structure of CrmE10, two identical molecules were found in one asymmetric unit. The CrmE10 structure was composed of 12 $\alpha$-helices (including three $3_{10}$-helices) and $5 \beta$-strands. The $\mathrm{N}$-terminal region had a compact architecture that was mainly composed of five predominant $\beta$-strands $(\beta 1-$ $\beta 5)$ surrounded by eight $\alpha$-helices $(\alpha 1-\alpha 8)$. The $\mathrm{C}$-terminal region was a long $\alpha$-helix, $\alpha 9$ (Ala184-Asp203), that extended away from the subunit core and wrapped in the other chain. Thus, CrmE10 formed an intertwined dimer though the swapped C-terminal domain (Fig. 2a).

AlinE4 structure was determined using esterase TesA (PDB code: 4jgg) as an initial search model, which revealed similar topology with CrmE10 (Fig. 2b). AlinE4 had one molecule in an asymmetric unit and was consisted of $11 \alpha$-helices (including two $3_{10}$ helices) and 5 predominant $\beta$-strands. AlinE4 had a similar topology with CrmE10, as well as the $\alpha 9$ (Ala168-Ala185) wrapped in other chains and formed a symmetric dimer through the swapped C-terminal domain (Fig. 2c and d). The capdomains and nucleophilic elbows were extensively important components of most other lipolytic enzyme families; however, they were not presented CrmE10 and AlinE4 [31-33]. Furthermore, the PISA analysis for CrmE10 and AlinE4 on the PDBePISA server showed that the multimeric state was 2 for the two enzymes, and the buried areas between two subunits were $8150 \AA^{2}$ (CrmE10) and $8010 \AA^{2}$ (AlinE4), respectively. This suggested CrmE10 and AlinE4 were a dimer in crystal structure.

\section{Structural comparison of CrmE10 and AlinE4 with other homologs}

CrmE10 shared 28.42\% (89\% coverage), $32.04 \%$ (88\% coverage), and $34.76 \%$ (80\% coverage) sequence identities with its homologous EstA (PDB code: 3HP4) [5], TAP (PDB code: $1 \mathrm{IVN}$ ) [14], and TesA (PDB code: 4JGG) [17], respectively. AlinE4 shared $31.33 \%$ ( $87 \%$ coverage), $39.51 \%$ ( $89 \%$ coverage), and $39.26 \%$ ( $85 \%$ coverage) identities with these proteins, respectively. However, the overall structures among CrmE10, AlinE4, EstA, TAP, and TesA were very similar, evidenced by the low RMSD values of $C \alpha$ atoms. For CrmE10 with EstA, TAP, and TesA, the values were $1.22 \AA, 1.02 \AA$, and $1.25 \AA$, respectively. For AlinE4 with EstA, TAP, and TesA, the values were $1.136 \AA$, $1.082 \AA$, and $0.979 \AA$, respectively. The obvious difference was at the loop between $\alpha 8$ and $\alpha 9$ and an $\alpha$-helix ( $\alpha 9)$ in the C-terminal region (Fig. 3a). In CrmE10 and AlinE4, the loop and the $\alpha 9$-helix extended away and were wrapped with the other chain in 


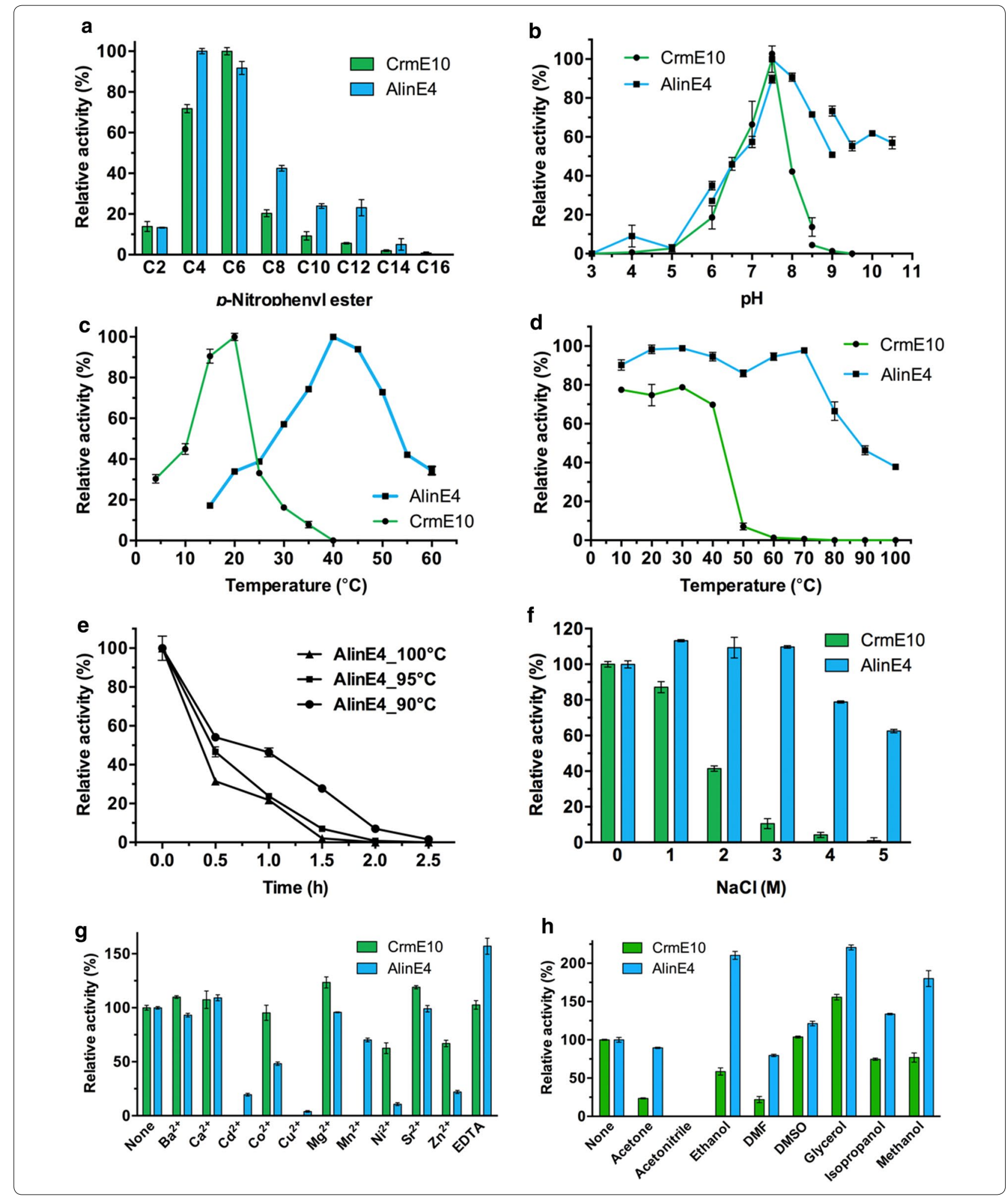

the dimeric structure; whereas in EstA, TAP, and TesA, which have been proved that they can catalyze substrates by one molecule, this region was embedded inward and surrounded by predominant $\beta$-strands with other helices. However, in CrmE10 and AlinE4, the $\alpha 8-\alpha 9$ loop and $\alpha 9$-helix of the other chain were highly conserved 


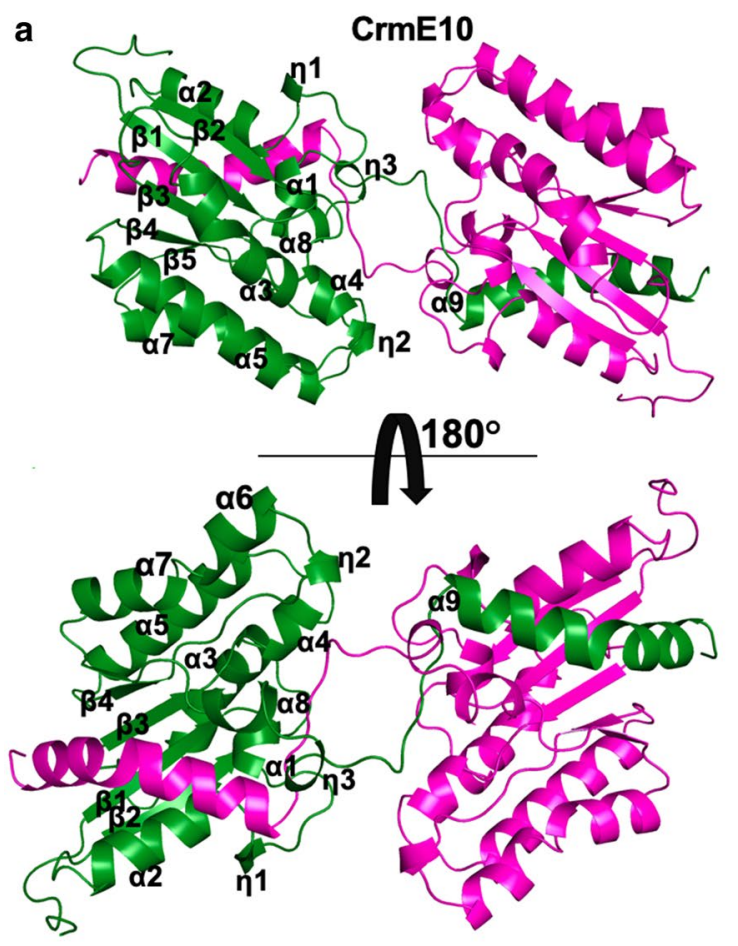

b
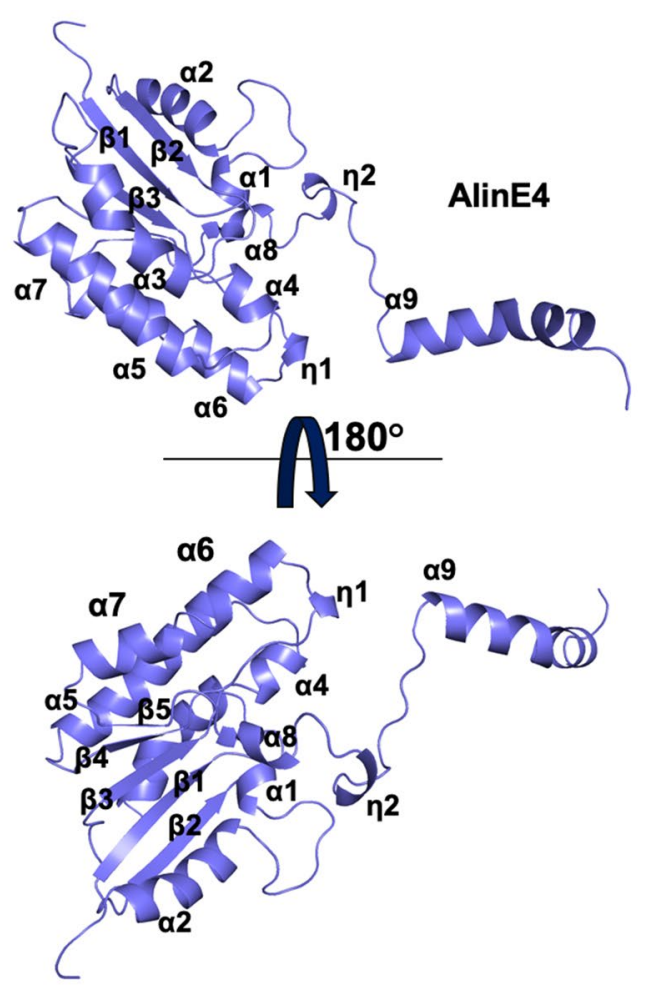

C

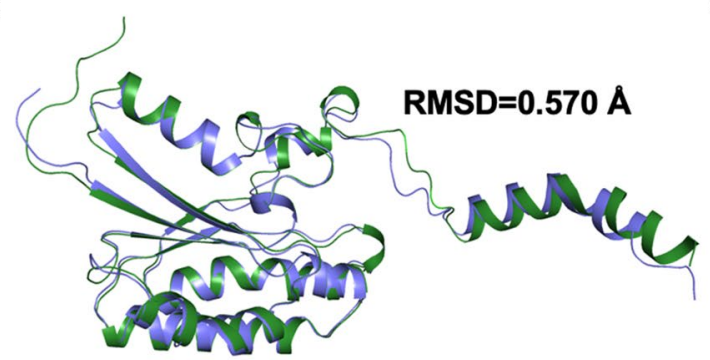

d

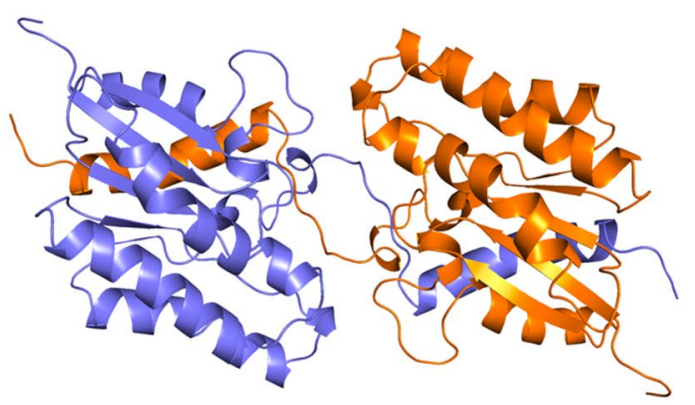

Fig. 2 Schematic representations of CrmE10 (PDB: 7C23) and AlinE4 (PDB: 7C82) crystal structures. Cartoon representations of CrmE10 (a) and AlinE4 (b). The two chains of CrmE10 are labeled in green and magenta; AlinE4 is labeled in blue. c The structural superposition of CrmE10 (green) and AlinE4 (blue). The overall structures are very similar with an RMSD value of $0.57 \AA$. $\mathbf{d}$ The dimeric model of AlinE4. The two subunits are in blue and orange, respectively

with the same regions, suggesting that the catalytic reaction of CrmE10 and AlinE4 required coordination of two molecules, which might be a new mechanism of SGNHhydrolase family esterases (Fig. 3b).

\section{Dimerization contributed to the catalytic activities of CrmE10 and AlinE4}

According to sequence alignment, the catalytic triad of CrmE10 consisted of Ser29, Asp178, and His181, and it was composed of Ser13, Asp162, and His165 in AlnE4 (Additional file 1: Fig. S2). Mutants CrmE10-S29A, CrmE10-D178A, and CrmE10-H181A had no enzymatic activities, which confirmed that these residues were crucial for the activity (Additional file 1: Fig. S4A). In CrmE10 and AlinE4 structures, catalytic residue Ser was located on helix $\alpha 1$, and residues Asp and His were located on the loop between helix $\eta 3$ (CrmE10) or helix $\eta 2$ (AlinE4) and helix $\alpha$, which were typically different from other esterases. Interestingly, the catalytic triads of CrmE10 and AlinE4 were not composed of Ser, Asp, and His from the same chain, which was common in other esterases (Fig. 4). For AlinE4, residues Ser13 and Asp162 on chain A and His165 on chain B were in a reasonable position of the catalytic triad, of which hydrogen bonds 

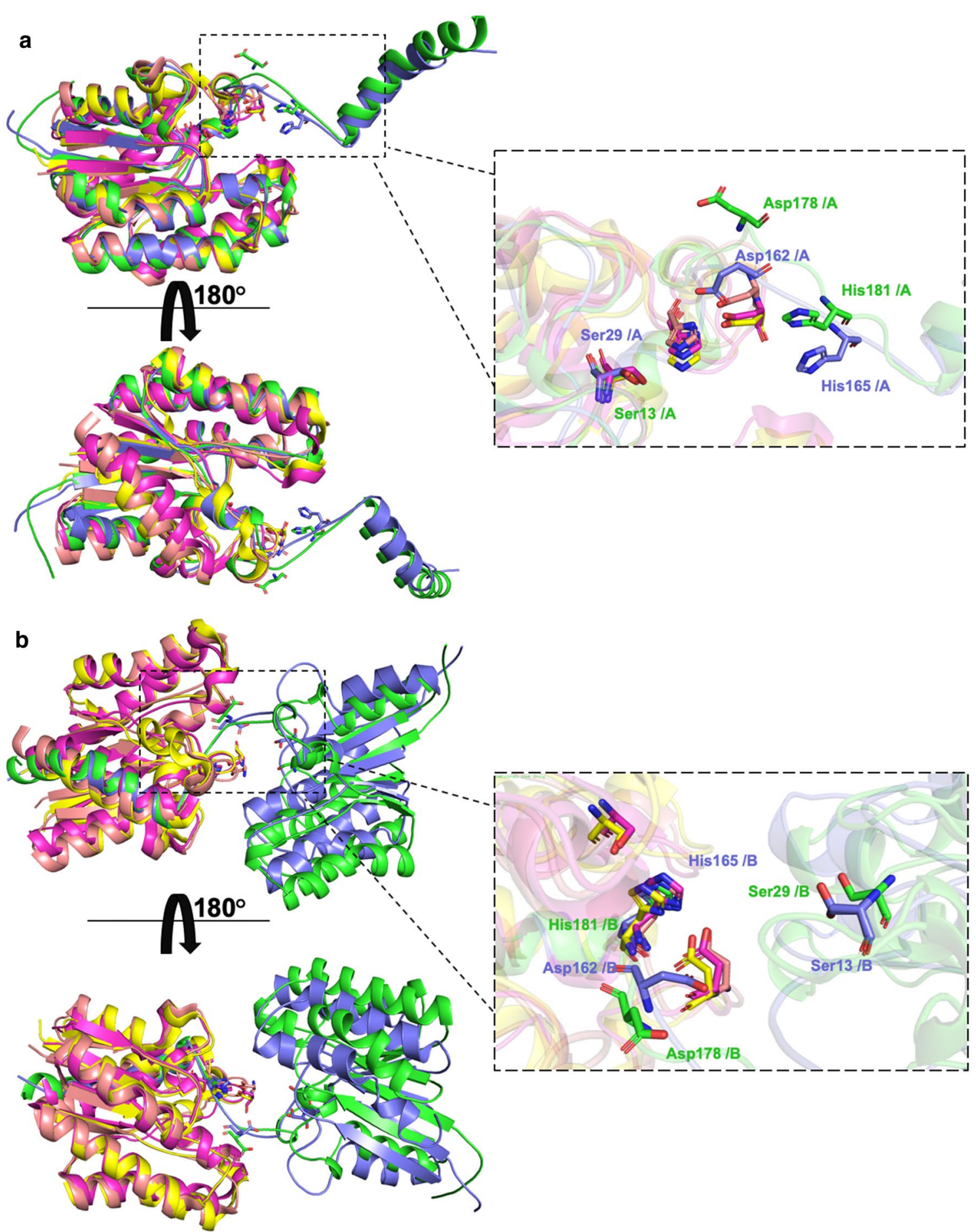

Fig. 3 Structure comparison of CrmE10 (PDB: 7C23) and AlinE4 (PDB: 7C82) with other homologs. a The structural superposition of CrmE10 (green), AlinE4 (blue), EstA (magenta, PDB code: 3HP4, from Pseudoalteromonas sp.), TAP (yellow, PDB code: 1IVN, from E. coli), and TesA (orange, PDB code: 4JGG, from P. aeruginosa). The major difference was in the catalytic pocket. $\mathbf{b}$ The structural superposition of the swap chain of CrmE10 and AlinE4 with these homologs. The catalytic residues are indicated with sticks 

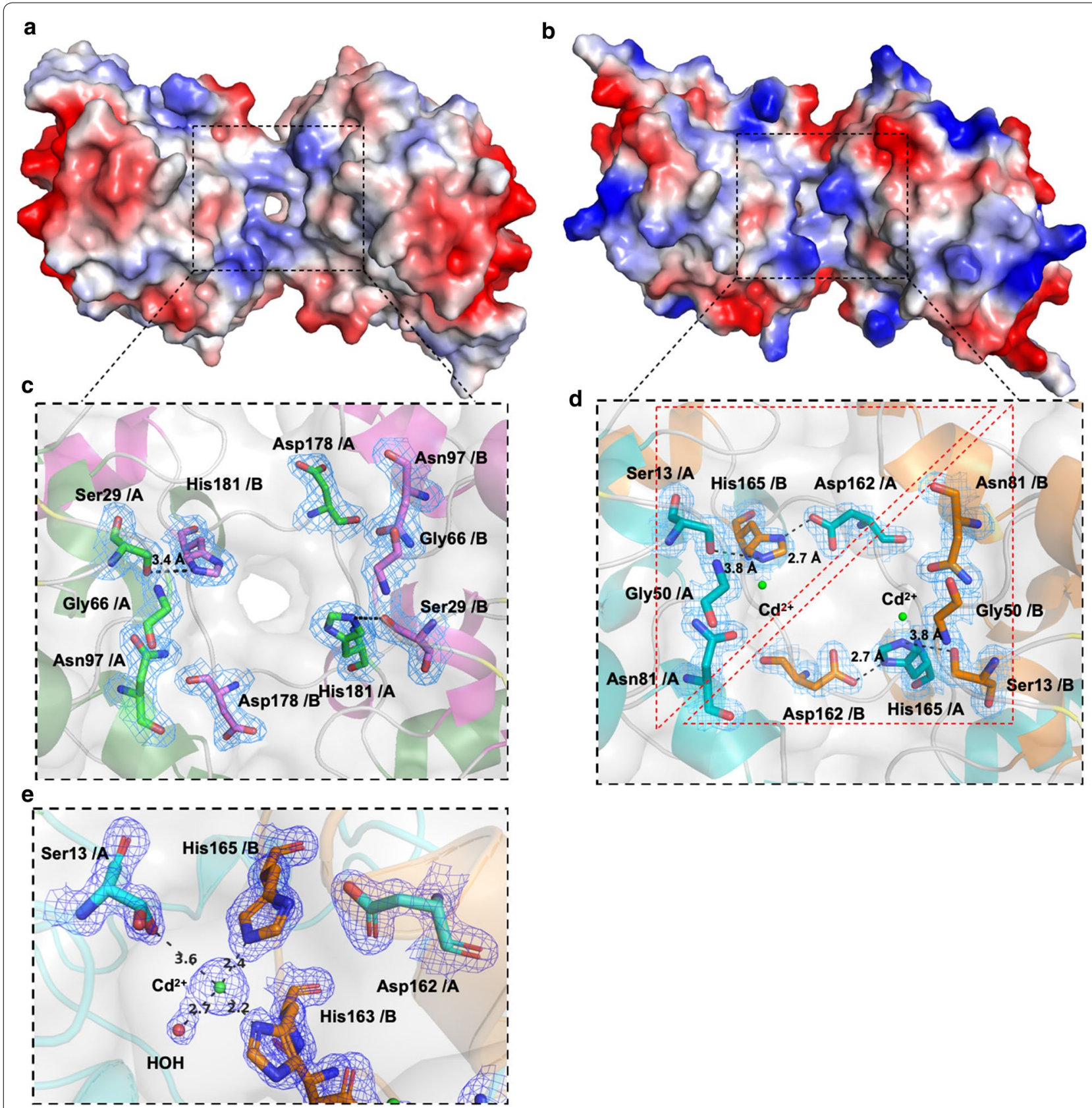

Fig. 4 Visualization of the catalytic sites of CrmE10 (PDB: 7C23) and AlinE4 (PDB: 7C82). CrmE10 (a) and AlinE4 (b) are shown with electrostatic potential surfaces. Red: negative potential; blue: positive potential. The residues of the catalytic triad and oxyanion hole of CrmE10 (c) and AlinE4 (d) are shown as stick models. The $\mathrm{Cd}^{2+}$ ions in AlinE4 are shown as green spheres. The electronic density map is contoured to $1.0 \sigma$ at the $2 F o-F c$ map. The dashed lines denoted hydrogen bonds. e The metal ion $\mathrm{Cd}^{2+}$ interacted with residues in the catalytic triad. The corresponding residues are indicated with a stick model. The electronic density map is contoured to $1.0 \sigma$ at the $2 F o-F c$ map. The $\mathrm{Cd}^{2+}$ is shown as a green ball and the water molecule is shown as a red ball

within the catalytic triad could be formed from Ser13-OY to His165-Nع2 and from His165-N81 to Asp162-O 81 (Fig. 4b, d). In mutants AlinE4-S13A, AlinE4-D162A, and AlinE4-H165A, catalytic activities toward $p$-NP esters were almost abolished (Additional file 1: Fig. S4B).
Moreover, substrates $p$-NP butyrate and $p$-NP hexanoate could be successfully docked into the active sites of AlinE4 and CrmE10 using AutoDock software, respectively (Additional file 1: Fig. S4C and D). In CrmE10, the active sites Ser and His also formed hydrogen bonds 
between Ser29-Oy and His181-Nع2 (3.4 A//3.9 ̊) (Fig. 4a, c).

As the catalytic triad was composed of the swapped dimeric structure, to further identify dimerization contributes to the catalytic activities of CrmE10 and AlinE4, mutagenesis analysis was performed for residues Asp178 and Ser29. The polycistronic plasmid CrmE10-W1 was composed of His-sumo-tagged WT CrmE10 and untagged mutant CrmE10-D178A, whereas the plasmid CrmE10-W2 was composed of His-sumo-tagged CrmE10 and untagged mutant CrmE10-D178A-S29A. The heated proteins did not have enzymatic activities and were used as a control. After expression and purification from E. coli, CrmE10-W1 had higher enzymatic activity than CrmE10-W2 (Additional file 1: Fig. S4A). As mutants CrmE10-S29A and CrmE10-D178A had no activity, the results showed that residues Ser29 and Asp178 influenced the enzymatic activity of CrmE10 by domain swapping. Thus, dimerization participated in the active sites of CrmE10, and this mechanism might also fit AlinE4 due to the similar architecture, which was different from other homologs.

\section{Metal ion $\mathrm{Cd}^{2+}$ affected the catalytic activity of AlinE4}

The mechanism of SGNH-hydrolase family esterase activity involves a two-step reaction (acylation and deacylation) similar to those proposed for lipolytic enzymes and serine proteases [34]. In this reaction, Ser is a nucleophile residue, and His is the proton donor/ acceptor [32]. Many heavy metal ions have impacts on enzymatic activity, but the mechanism was not clear [12, 35-37]. There was one density map around the catalytic sites in the crystal structure of AlinE4, which turned out to be one $\mathrm{Cd}^{2+}$ evidenced by electrochemistry analysis (Additional file 1: Table S2). According to the characterization of AlinE4, $\mathrm{Cd}^{2+}$ had negative impacts on the enzymatic activity of AlinE4, evidenced by only retaining $20 \%$ activity at $10 \mathrm{mM} \mathrm{CdCl}_{2}$ (Fig. $1 \mathrm{~g}$ ). In the crystal structure of AlinE4, $\mathrm{Cd}^{2+}$ interacted with residues Ser13 and His165, which were components of the catalytic triad (Fig. 4e). The results suggested that $\mathrm{Cd}^{2+}$ might act on activity through (i) blocking proton transfer and (ii) protecting substrates from nucleophile attack.

\section{Structure-based mutation dramatically increased the enzymatic activity}

CrmE10 and AlinE4 shared similar atomic architectures (RMSD value of $C \alpha$ was $0.570 \AA$, Fig. 2 c); however, the enzymatic properties exhibited significant difference, including substrate specificity, alkaline adaptability, temperature adaptability, metal ion tolerance, and organic solvent tolerance (Fig. 1a-h). To further investigate the possible mechanism, we analyzed the sequences based on the 3D structures and found five specific residues might contribute to these enzymatic property difference. The residues were acidic in CrmE10, including Asp77, Glu86, Asp123, Glu159, and Asp200, whereas the corresponding residues were basic in AlinE4, including Lys61, Lys70, Lys107, Lys143, and Lys184 (Additional file 1: Fig. S2). The region of these five sites in CrmE10 formed a negative potential surface; however, the corresponding region was full of positive potential in AlinE4.

AlinE4 exhibited high alkaline adaptability evidenced by retaining about $60 \%$ activity at $\mathrm{pH} 10.5$, whereas CrmE10 only retained about $10 \%$ activity at $\mathrm{pH} 8.5$ (Fig. 1b). The enzymatic assay results showed that mutants AlinE4-K61D, AlinE4-K107D, and AlinE4K143E retained about $45 \%$ or lower activity when $\mathrm{pH}$ was equal to or higher than 9.0 (Fig. 5c). The engineered enzyme CrmE10-mut5 (D77K/E86K/D123K/E159K/ D200K) significantly increased to about $20 \%$ activity at pH 10, whereas CrmE10-E159K/D200K increased a little enzymatic activity at $\mathrm{pH}$ 9.0-9.5 and CrmE10-mut3 (D77K/E86K/D123K) had no difference as compared to wild-type CrmE10 (Fig. 5b), which meant these five sites synergistically participated in alkaline adaptability. The mutants of these five residues might change the surface charge of CrmE10 and increase its stability in an alkaline environment, therefore increasing its activity. AlinE4 had higher enzymatic activity toward long-chain substrates (C8, C10, C12 and C14) than CrmE10 (Fig. 1a). Compared with wild-type CrmE10, CrmE10-mut5 exhibited higher activity toward long-chain substrates (Additional file 1: Fig. S5A), which suggested these five sites might contribute to substrate binding. Furthermore, the temperature preferences of mutants CrmE10-mut5 and CrmE10-E159K/D200K were different from wild-type CrmE10 (Additional file 1: Fig. S5B). Mutants CrmE10mut5 and CrmE10-E159K/D200K exhibited more than $50 \%$ activity with the addition of $10 \mathrm{mM} \mathrm{Cd}^{2+}$ or $\mathrm{Mn}^{2+}$, which completely inhibited wild-type CrmE10 activity. Moreover, these two engineered enzymes had lower activities with the addition of $10 \mathrm{mM} \mathrm{Ni}^{2+}$ than wild-type CrmE10, which was similar to AlinE4 (Additional file 1: Fig. S5C). Besides, compared with wild-type CrmE10, CrmE10-mut5 exhibited higher activity with the addition of DMF or DMSO (Additional file 1: Fig. S5D). Therefore, changing the charge properties of the esterases would dramatically affect the enzymatic properties.

\section{Discussion}

SGNH-hydrolase family esterases play essential roles in food, pharmaceutical, and biological industries [3]. Our study revealed a new catalytic mechanism for two esterases from different sources. The swapped domains in the dimers of CrmE10 and AlinE4 contributed to the 


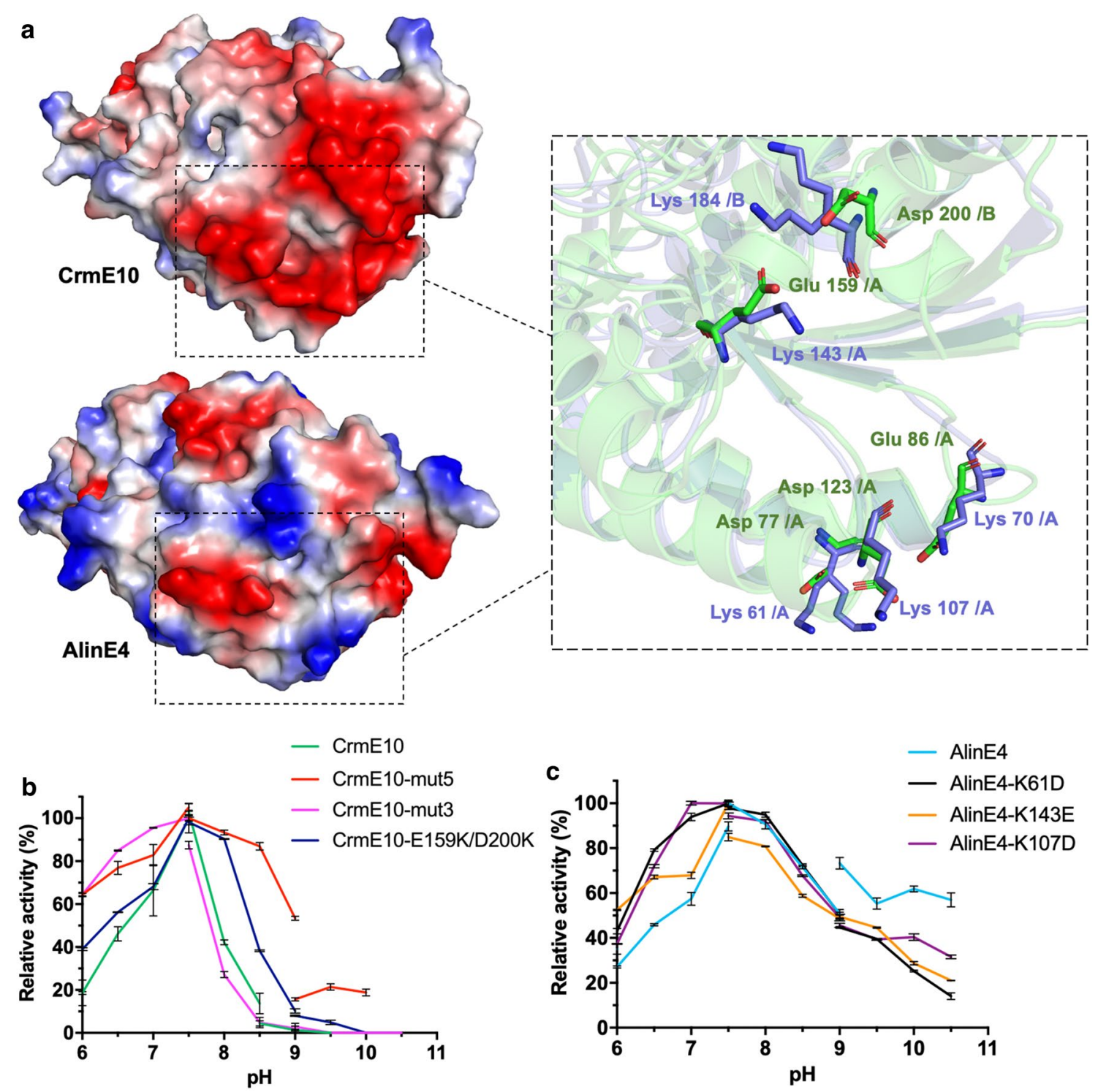

Fig. 5 The key residues associated with alkaline adaptability. a CrmE10 (top, PDB: 7C23) and AlinE4 (bottom, PDB: 7C82) are indicated in electrostatic potential surfaces. Red: negative potential; blue: positive potential. Five residues associated with of alkaline adaptability are indicated in sticks (green: CrmE10, blue: AlinE4). Enzymatic activities of CrmE10 (b) and AlinE4 (c) and their mutants determined with a range of different pH values. The value obtained at $\mathrm{pH} 7.5$ was taken as $100 \%$. The gap was between different $\mathrm{pH}$ due to the buffer changing

enzymatic reaction, which was different from the catalytic mechanism in other esterases, such as EstA [5], TesA [17], and TesI [14]. Although the MALS results suggested that CrmE10 and AlinE4 are monomers in solution (Additional file 1: Fig. S3C and D), the crystal structures and PISA analysis showed that the two esterases could form dimers by the swapped domains. The dimeric structures could contribute to the enzymatic activities and help the stabilization for crystal packing (Additional file 1: Fig. S4), which was similar to the reported human archease [38]. The esterases SsEst from
Streptomyces scabies and NanS from E. coli were reported to possess catalytic Ser-His dyads [7, 39]. The correct orientation of the imidazole ring of His in SsEst was ensured by a hydrogen bond between His-N $\delta 1$ and a main chain carbonyl oxygen [7]. In NanS, only the catalytic dyad residues Ser and His were essential for catalysis, and it was hypothesized that the hydroxyl ion played the catalytic role or that substrate binding caused active site reorganization [39]. In SGNH-hydrolase family enzymes, the residue Ser on the catalytic triad was considered an essential element for aromatic acyl substrate binding, and 
His was considered as the proton donor/acceptor [32, 40]. However, the function of the Asp residue was barely investigated. The loop between $3_{10}$-helix $\eta 3$ and helix $\alpha 9$, on which the catalytic Asp residue was located, showed significant conformational change between the WT and mutant CrmE10 (Fig. 6a) and had a higher B-factor (Fig. 6b, c). The higher B-factor of the loop implied flexibility in its structure and function. Hence, this Asp might participate in destabilizing the conformation of the loop in the resting state and in changing it to a more stable conformation when the substrate bound the enzyme. Although the mutant AlinE4-D162A did not show significant variation compared with wild-type AlinE4, the B-factor of this loop was lower than wild-type AlinE4 (Additional file 1: Fig. S6). These results revealed that the Asp in the catalytic triad destabilized the conformation of the reaction pocket.

Currently, many protein engineering methods have been developed to improve esterases (or lipases) properties, including substrate specificity [41, 42], activity $[43,44]$, thermostability [45], and enantioselectivity [46, 47]. However, limited studies for enhancing alkali tolerance have been reported, especially based on structural information. Although esterase CrmE10 and AlinE4 exhibited similar atomic architectures as well as similar swap catalytic mechanisms, they had distinctly different electrostatic surface potentials, as well as different alkaline adaptability, thermal stability, salt tolerance, and heavy metal ions tolerance (Figs. 1 and 2). Structureguided mutation in aspartic acid/glutamic acid to lysine increased the alkaline adaptability (Fig. 5). The mutants of CrmE10-mut5 and CrmE10-E159K/D200K exhibited different properties from wild-type CrmE10 (Additional file 1: Fig. S5). According to previous studies, the thermal stability can be affected by (i) more abundant, high hydrophobicity, charged residues (such as Glu, Arg, and Lys) rather than uncharged polar amino acid (such as Ser, Thr, Asn, and Gln) in the amino acid sequences [41, 48, 49]; (ii) more $\alpha$-helices in structures [50, 51]; and (iii) some intermolecular forces, such as hydrogen bonds [52]. AlinE4 has 6 glutamine residues and 12 lysine residues, while CrmE10 has 12 glutamine residues and only 1 lysine residue, which might lead to the difference in thermal stability. The salt tolerance might be affected by charges on the surface. When the surface charges were calculated using PyMOL software, the values of CrmE10 and AlinE4 were -37 and 0 , respectively, which indicated AlinE4 had a nonpolar surface and its enzymatic activity was not susceptible to salt. Therefore, structure-guided protein engineering for hydrolases might increase the potential industrial and pharmaceutical uses through simply changing the charged residues.

\section{Conclusions}

Here, we reported the enzymatic characterizations and crystal structures of marine bacterial esterases CrmE10 and AlinE4. The two enzymes shared high sequence similarity and similar atomic architectures; however, they had significantly different enzymatic activities. Despite sharing a similar swapping catalytic mechanism, CrmE10

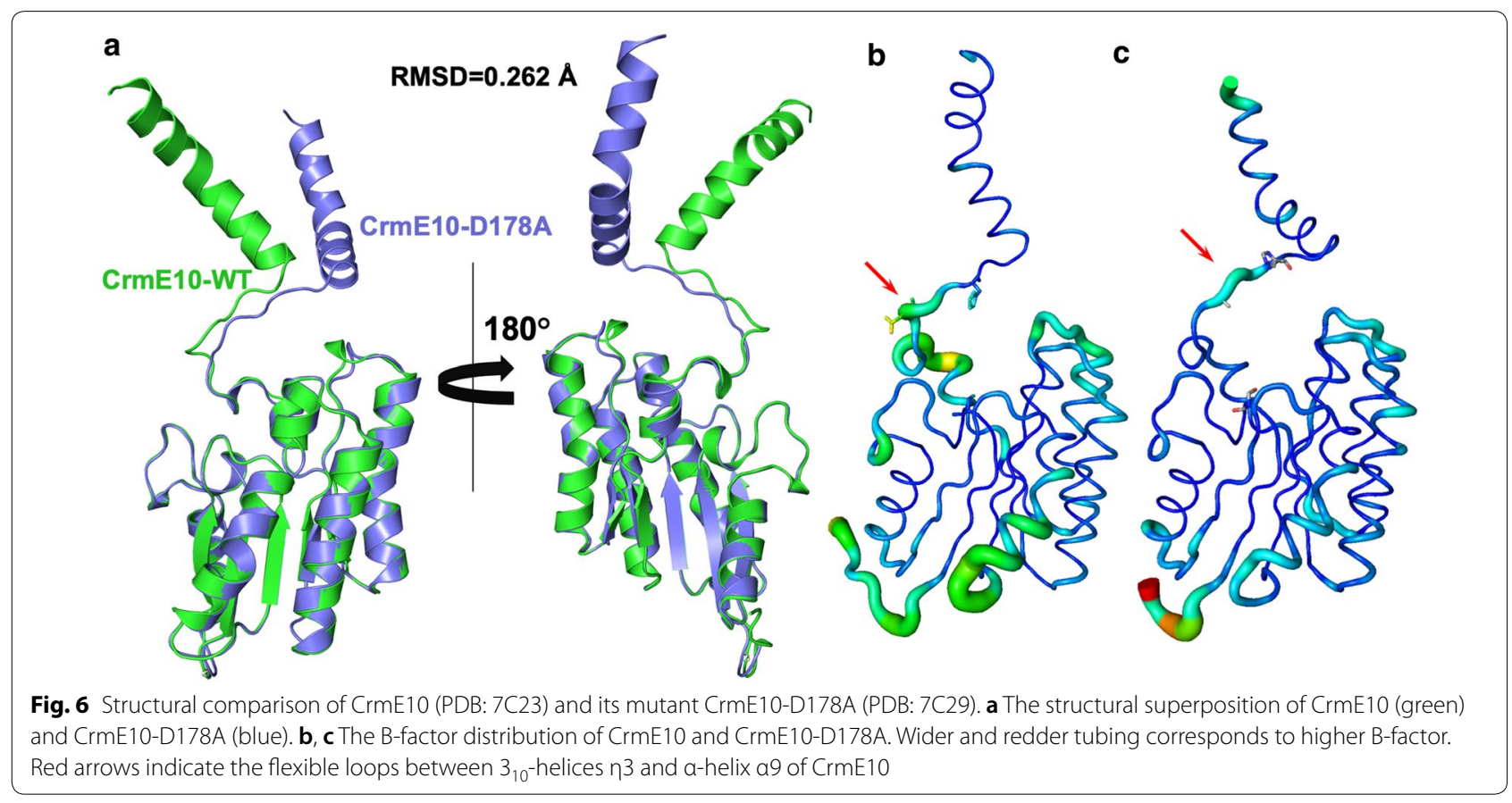


and AlinE4 had distinctly different electrostatic surface potentials. Structure-based mutation showed that CrmE10 obtained elevated alkaline adaptability and had a significant increase in enzymatic activity from 0 to $20 \%$ at $\mathrm{pH} 10.5$ when five acidic residues were mutated to the corresponding basic residues in AlnE4. In addition, one key residue (Asp162 in AlinE4/Asp178 in CrmE10) was found to be able to stabilize the conformation of both esterases and the metal ion $\mathrm{Cd}^{2+}$ reduced enzymatic activity by blocking proton transfer and substrate binding. Our current findings offer a perspective for understanding the catalytic mechanism of esterases and could facilitate industrial biocatalytic applications of these esterases.

\section{Materials and methods}

\section{Cloning, mutation, protein expression, and purification}

Croceicoccus marinus $\mathrm{E} 4 \mathrm{~A} 9^{\mathrm{T}}$ was previously isolated from a deep-sea sediment sample [25] and was stored in our lab. Altererythrobacter indicus DSM $18604^{\mathrm{T}}$ was isolated from mangrove-associated wild rice [26] and was purchased from Leibniz Institute DSMZ-German Collection of Microorganisms and Cell Cultures. The genes crme10 and aline 4 were cloned into plasmid pSMT3 to produce the $\mathrm{N}$-terminal His-Sumo tagged fusion proteins from the genomic DNA of C. marinus $\mathrm{E} 4 \mathrm{AA} 9^{\mathrm{T}}$ and A. indicus DSM $18604^{\mathrm{T}}$, respectively. Point mutants were generated by site-directed mutagenesis using wild-type plasmids as templates for PCR. After digested with $D p n \mathrm{I}$ enzyme, the products were transformed into E. coli DH5 $\alpha$ cells and determined by DNA sequencing. CrmE10-W1 contains wild-type CrmE10, ribosomal binding site (RBS) and CrmE10-D178A in the pSMT3 plasmid, whereas the polycistronic CrmE10-W2 plasmid contains wildtype CrmE10, ribosome binding sites, and CrmE10D178A-S29A. The wide-type and mutated proteins were expressed in E. coli BL21 (DE3) cells. The cells were cultured in LB broth medium induced by adding $0.5 \mathrm{mM}$ isopropyl- $\beta$-D-thiogalactoside (IPTG), when $\mathrm{OD}_{600}$ came to $0.6-0.8$. After cultivation at $16{ }^{\circ} \mathrm{C}$ for $20 \mathrm{~h}$, cells were harvested by centrifugation at $6000 \mathrm{rpm}$ for $15 \mathrm{~min}$ at $4{ }^{\circ} \mathrm{C}$, resuspended in starting buffer $(50 \mathrm{mM}$ Tris- $\mathrm{HCl}$, $500 \mathrm{mM} \mathrm{NaCl}, 10 \mathrm{mM}$ imidazole, 5\% glycerol, pH 8.0), and disrupted by French press homogenizer (JNBio, China). Cell debris was removed by centrifugation and the supernatant was incubated with Ni Sepharose (GE, USA) for $1 \mathrm{~h}$. After washing with buffer 1 (50 mM Tris$\mathrm{HCl}, 500 \mathrm{mM} \mathrm{NaCl}, 50 \mathrm{mM}$ imidazole, $5 \%$ glycerol, $\mathrm{pH}$ 8.0), the recombinant protein was eluted with buffer 2 (50 mM Tris- $\mathrm{HCl}, 500 \mathrm{mM} \mathrm{NaCl}, 250 \mathrm{mM}$ imidazole, $5 \%$ glycerol, $\mathrm{pH}$ 8.0). Subsequently, the His-Sumo tag was removed by overnight digestion with the ULP1 enzyme. The recombinant target proteins were further purified by gel-filtration using the Superdex 200 10/300 column (GE, USA) in a buffer ( $20 \mathrm{mM}$ Tris- $\mathrm{HCl}, 100 \mathrm{mM} \mathrm{NaCl}, 2 \mathrm{mM}$ DTT, $\mathrm{pH}$ 7.4). The fractions of elution were determined by sodium dodecyl sulfate polyacrylamide gel electrophoresis (SDS-PAGE). Furthermore, the protein concentrations were determined by the Bradford method [53] with bovine serum albumin (BSA) as standard.

\section{Sequence analysis}

Multiple alignments of amino acid sequences were performed using ClustalX v.2 program [54]. Secondary structure alignment was generated by DSSP v.2.0 [55] and ESpript v.3.0 (http://espript.ibcp.fr/ESPript/ESPri pt/) [56]. The phylogenetic tree was constructed by the neighbor-joining method using MEGA (Molecular Evolutionary Genetics Analysis) v.7.0 software [29].

\section{Multi-angle light scattering (MALS) analysis}

MALS analysis was performed in the National Center for Protein Science Shanghai (NCPSS). $20 \mu \mathrm{l}$ of $1 \mathrm{mg} /$ $\mathrm{ml}$ purified target protein was subjected to SEC-MALS using a WTC-030S5 size-exclusion column (Wyatt, USA) with elution buffer (20 mM Tris-HCl, pH 7.4, $100 \mathrm{mM}$ $\mathrm{NaCl}$ ) and passed in tandem through a Wyatt DAWN HELEOS II light scattering instrument (Wyatt, USA) and an optilab refractometer (Wyatt, USA). Data collection and analysis were performed with Astra 6 software (Wyatt, USA).

\section{Enzymatic activity assays}

Esterase activity assays were performed using a spectrophotometric method with the appropriate amount of purified enzyme in standard reaction buffer containing $100 \mathrm{mM}$ Tris $-\mathrm{HCl}(\mathrm{pH} 7.5)$, enzyme (concentration at $1-5 \mu \mathrm{g} / \mathrm{mL}$ ) and $1 \mathrm{mM} p$-nitrophenyl ( $p$-NP) hexanoate (for CrmE10 and its mutants, TCI, Japan), or $p$ NP butyrate (for AlinE4 and its mutants, Sigma-Aldrich, USA). The enzymatic activity was determined at $20{ }^{\circ} \mathrm{C}$ (for CrmE10 and its mutants) or $40{ }^{\circ} \mathrm{C}$ (for AlinE4 and its mutants) by measuring the amount of releasing p-nitrophenol using Beckman Coulter DU 800 UV/Visible spectrophotometer (Beckman, USA) at $405 \mathrm{~nm}$. All values were measured in triplicates and corrected for the autohydrolysis of the substrates. One unit of enzymatic activity was defined as the amount of enzyme required for releasing $1 \mu \mathrm{mol}$ of $p$-nitrophenol per minute from the $p$-nitrophenyl ester. The kinetic parameters $\left(K_{\mathrm{m}}\right.$ and $\left.V_{\max }\right)$ were calculated from enzymatic activity measurements with $p$-NP hexanoate (for CrmE10) or $p$-NP butyrate (for AlinE4) ranging from $0.05 \mathrm{mM}$ to $2 \mathrm{mM}$. Initial reaction velocities measured at various concentrations were fitted to the Lineweaver-Burk transformation of the Michaelis-Menten equation [57]. 
The optimum $\mathrm{pH}$ of esterases $\mathrm{CrmE} 10$ and AlinE4 was determined over the $\mathrm{pH}$ range from 3.0 to 9.5. The buffers included citrate buffer (100 mM, pH 3.0-6.0), phosphate buffer (100 mM, pH 6.0-7.5), Tris- $\mathrm{HCl}$ buffer (100 mM, pH 7.5-8.5 or 7.5-9.0), and CHES-NaOH buffer (50 mM, pH 8.5-10.5 or 9.0-10.5). The enzymatic activity was measured under $348 \mathrm{~nm}$. The effects of temperature on esterases $\mathrm{CrmE} 10$ and AlinE4 were measured over a range of $15-60{ }^{\circ} \mathrm{C}$. For investigation of the thermostability, the residual activity of CrmE10 and AlinE4 was determined after incubation at various temperatures ranging from $10{ }^{\circ} \mathrm{C}$ to $100{ }^{\circ} \mathrm{C}$ for $1 \mathrm{~h}$. And the thermostability of AlinE4 was further determined after incubation at $90^{\circ} \mathrm{C}, 95^{\circ} \mathrm{C}$ and $100^{\circ} \mathrm{C}$ for $0-2.5 \mathrm{~h}$.

Various chain lengths of $p$-NP esters, including $p$-NP acetate (C2), $p$-NP butyrate (C4), $p$-NP hexanoate (C6) (TCI, Japan), $p$-NP octanoate (C8), $p$-NP decanoate (C10), $p$-NP dodecanoate (C12), myristate (C14), and $p$-NP palmitate (C16) (Sigma-Aldrich, USA, unless otherwise stated) were added into the reaction buffer with final concentration of $1 \mathrm{mM}$ for determining substrate specificity.

The effects of $\mathrm{NaCl}$ on $\mathrm{CrmE10}$ and AlinE4 activity were evaluated by adding $0-5 \mathrm{M} \mathrm{NaCl}$ to the assay mixture. The effects metal ions were measured using various divalent cations, namely $\mathrm{Zn}^{2+}, \mathrm{Sr}^{2+}, \mathrm{Ni}^{2+}, \mathrm{Mn}^{2+}, \mathrm{Mg}^{2+}$, $\mathrm{Co}^{2+}, \mathrm{Ca}^{2+}$, and $\mathrm{Ba}^{2+}$, at final concentration of $10 \mathrm{mM}$. The effect of the chelating agent ethylenediaminetetraacetic acid (EDTA) was determined at a final concentration of $10 \mathrm{mM}$. The effects of organic solvents were determined using acetone, acetonitrile, ethanol, dimethylformamide (DMF), dimethyl sulfoxide (DMSO), glycerol, isopropanol, and methanol, at a final concentration of $15 \%(\mathrm{v} / \mathrm{v})$.

\section{Electrochemistry analysis}

Several crystals of AlinE4 were washed in a Tris buffer without heavy metal ions for several seconds and transferred into a micro-centrifuge tube. Then the crystals were dissolved completely with the Tris buffer. The protein concentration was measured by the Bradford method [53]. The 884 professional VA (Metrohm Co., Ltd) was used to measure the type of ion through the Anodic Stripping Voltammetry [58-60], and the concentration of cadmium was calculated by comparing with the standard solution. All experiments were repeated three twice.

\section{Crystallization and X-ray data collection}

CrmE10 and AlinE4 were applied to crystallization trials carried out at $20{ }^{\circ} \mathrm{C}$ by hanging- and sitting-drop vapordiffusion methods by mixing $30 \mathrm{mg} / \mathrm{ml}$ protein with an equal volume reservoir solution. The crystals of native CrmE10 were grown in a reservoir solution containing
$150 \mathrm{mM}$ calcium acetate, $100 \mathrm{mM}$ imidazole- $\mathrm{HCl}(\mathrm{pH}$ 8.0 ), and $10 \%$ PEG 8000 . The crystals were briefly soaked in $25 \%(\mathrm{v} / \mathrm{v})$ glycerol dissolved in their reservoir solution, as a cryoprotectant solution, before being flashfrozen directly in liquid nitrogen. The CrmE10-D178A crystals were grown in the condition of $250 \mathrm{mM}$ calcium acetate, $100 \mathrm{mM}$ imidazole- $\mathrm{HCl}$ (pH 8.5), 5\% PEG 1000, and 3\% 1,6-Hexanediol. The cryoprotectant solution of the CrmE10-D178A crystals was 20\% (v/v) PEG 400. The crystals of native AlinE4, AlinE4-S13A, and AlinE4D178A were grown in $1 \mathrm{M} \mathrm{NaAc}, 100 \mathrm{mM}$ HEPES, and $50 \mathrm{mM} \mathrm{CdSO}_{4}$. All X-ray diffraction datasets were collected at BL17U1 [61], BL18U1, and BL19U1 [62] beamlines of the Shanghai Synchrotron Radiation Facility (SSRF, China). Diffraction data were integrated and scaled using software HKL2000 [63].

\section{Structure analysis and refinement}

The crystal structures of wild-type (WT) CrmE10 and AlinE4 were determined by molecular replacement using esterase TesA (PDB code: 4jgg) [17] as the search model. The mutant protein structures were solved using the WT structure as the search model. After cycles of refinement and model building processed using program REFMAC5 $[64,65]$ of CCP4i and software COOT [66], the crystallography $\mathrm{R}$-free and $\mathrm{R}$-factor values reached to the satisfied range. PROCHECK [67] of PDBsum was used to evaluate the quality of the final $3 \mathrm{D}$-structures. The other homologous structures were identified using DALI server $[68,69]$ and blast program (https://blast.ncbi. nlm.nih.gov/Blast.cgi). Substrate docking studies were performed using the AutoDockTools4 program [70]. All the 3D-structures were analyzed and displayed using the PyMOL molecular graphics system (The PyMOL Molecular Graphics System, Version 2.0 Schrödinger, LLC). CrmE10, CrmE10-D178A, AlinE4, AlinE4-D162A, and AlinE4-S13A were deposited to Protein Data Bank with accession codes 7C23, 7C29, 7C82, 7C84, and 7C85, respectively. Data collection and refinement parameters are listed in Additional file 1: Table S1.

\section{Supplementary information}

Supplementary information accompanies this paper at https://doi. org/10.1186/s13068-020-01742-8.

Additional file 1. Additional figures and tables.

\section{Abbreviations}

p-NP: p-Nitrophenyl; MALS: Multi-angle light scattering; RMSD: Root-meansquare deviation; DMF: N,N-Dimethylformamide; DMSO: Dimethyl sulfoxide.

\section{Acknowledgements}

We thank the staff from the BL17U1/BL18U1/BL19U1 beamlines at the Shanghai Synchrotron Radiation Facility for assistance during data collection. 


\section{Authors' contributions}

$Z L, L L, Y H, Z C, Y Z, J H, S J, Z R, D W, J G$, and XH performed the experiments and analyzed the data. $J L$ and $X X$ designed the study and wrote the manuscript. All authors read and approved the final manuscript.

\section{Funding}

This work was supported by the Grants from National Key Research and Development Program of China (2016YFA0500600), China Ocean Mineral Resources R \& D Association (COMRA) Special Foundation (DY135-B2-10), the National Natural Science Foundation of China (31770004, 91851114), and the Shanghai Committee of Science and Technology (18430711400).

\section{Availability of data and materials}

The X-ray datasets generated for this study were deposited in the Protein data bank (PDB, http://www.rcsb.org/). The PDB codes of CrmE10, CrmE10-D178A, AlinE4, AlinE4-D162A, and AlinE4-S13A were 7C23, 7C29, 7C82, 7C84, and 7C85, respectively.

\section{Ethics approval and consent to participate}

Not applicable.

\section{Consent for publication}

All authors give consent to publish the research in Biotechnology for Biofuels.

\section{Competing interests}

The authors declare that they have no competing interests.

Received: 7 January 2020 Accepted: 30 May 2020

Published online: 15 June 2020

\section{References}

1. Arpigny JL, Jaeger KE. Bacterial lipolytic enzymes: classification and properties. Biochem J. 1999;343(Pt 1):177-83.

2. Molgaard A, Kauppinen S, Larsen S. Rhamnogalacturonan acetylesterase elucidates the structure and function of a new family of hydrolases. Structure. 2000;8(4):373-83.

3. Akoh CC, Lee GC, Liaw YC, Huang TH, Shaw JF. GDSL family of serine esterases/lipases. Prog Lipid Res. 2004;43(6):534-52.

4. Huo YY, Jian SL, Cheng H, Rong Z, Cui HL, Xu XW. Two novel deep-sea sediment metagenome-derived esterases: residue 199 is the determinant of substrate specificity and preference. Microb Cell Fact. 2018;17(1):16.

5. Brzuszkiewicz A, Nowak E, Dauter Z, Dauter M, Cieslinski H, Dlugolecka A, Kur J. Structure of EstA esterase from psychrotrophic Pseudoalteromonas sp. 643A covalently inhibited by monoethylphosphonate. Acta Crystallogr, Sect F: Struct Biol Cryst Commun. 2009;65(Pt 9):862-5.

6. van den Berg B. Crystal structure of a full-length autotransporter. J Mol Biol. 2010;396(3):627-33.

7. Wei Y, Schottel JL, Derewenda U, Swenson L, Patkar S, Derewenda ZS. A novel variant of the catalytic triad in the Streptomyces scabies esterase. Nat Struct Biol. 1995;2(3):218-23.

8. Kovačić F, Granzin J, Wilhelm S, Kojić-Prodić B, Batra-Safferling R, Jaeger KE. Structural and functional characterisation of TesA-a novel lysophospholipase A from Pseudomonas aeruginosa. PLoS ONE. 2013;8(7):e69125.

9. Lescic Asler I, Ivic N, Kovacic F, Schell S, Knorr J, Krauss U, Wilhelm S, KojicProdic B, Jaeger KE. Probing enzyme promiscuity of SGNH hydrolases. ChemBioChem. 2010;11(15):2158-67.

10. Ding J, Yu T, Liang L, Xie Z, Yang Y, Zhou J, Xu B, Li J, Huang Z. Biochemical characterization of a GDSL-motif esterase from Bacillus sp. K91 with a new putative catalytic mechanism. J Microb Biotechnol. 2014;24(11):1551-8.

11. Shakiba MH, Ali MS, Rahman RN, Salleh AB, Leow TC. Cloning, expression and characterization of a novel coldadapted GDSL family esterase from Photobacterium sp. strain J15. Extremophiles. 2016;20(1):44-55.

12. Wang G, Wang Q, Lin X, Ng TB, Yan R, Lin J, Ye X. A novel cold-adapted and highly salt-tolerant esterase from Alkalibacterium sp. SL3 from the sediment of a soda lake. Sci Rep. 2016;6:19494.

13. Robertson DL, Hilton S, Wong KR, Koepke A, Buckley JT. Influence of active site and tyrosine modification on the secretion and activity of the Aeromonas hydrophila lipase/acyltransferase. J Biol Chem. 1994;269(3):2146-50.
14. Lo YC, Lin SC, Shaw JF, Liaw YC. Crystal structure of Escherichia coli thioesterase I/protease I/lysophospholipase L1: consensus sequence blocks constitute the catalytic center of SGNH-hydrolases through a conserved hydrogen bond network. J Mol Biol. 2003;330(3):539-51.

15. Chang RC, Chen JC, Shaw JF. Vibrio mimicus arylesterase has thioesterase and chymotrypsin-like activity. Biochem Biophys Res Commun. 1995;213(2):475-83.

16. Grisewood MJ, Hernandez Lozada NJ, Thoden JB, Gifford NP, MendezPerez D, Schoenberger HA, Allan MF, Floy ME, Lai RY, Holden HM, et al. Computational redesign of Acyl-ACP thioesterase with improved selectivity toward medium-chain-length fatty acids. ACS Catal. 2017;7(6):3837-49.

17. Kovacic F, Granzin J, Wilhelm S, Kojic-Prodic B, Batra-Safferling R, Jaeger KE. Structural and functional characterisation of TesA-a novel lysophospholipase A from Pseudomonas aeruginosa. PLOS ONE. 2013;8(7):e69125.

18. Brick DJ, Brumlik MJ, Buckley JT, Cao JX, Davies PC, Misra S, Tranbarger TJ, Upton C. A new family of lipolytic plant enzymes with members in rice, arabidopsis and maize. FEBS Lett. 1995;377(3):475-80.

19. Beisson F, Gardies AM, Teissere M, Ferte N, Noat G. An esterase neosynthesized in post-germinated sunflower seeds is related to a new family of lipolytic enzymes. Plant Physiol Bioch. 1997;35(10):761-5.

20. Oh IS, Park AR, Bae MS, Kwon SJ, Kim YS, Lee JE, Kang NY, Lee S, Cheong $\mathrm{H}$, Park OK. Secretome analysis reveals an Arabidopsis lipase involved in defense against Alternaria brassicicola. Plant Cell. 2005;17(10):2832-47.

21. Hong JK, Choi HW, Hwang IS, Kim DS, Kim NH, Choi DS, Kim YJ, Hwang BK. Function of a novel GDSL-type pepper lipase gene, CaGLIP1, in disease susceptibility and abiotic stress tolerance. Planta. 2008;227(3):539-58.

22. Guther ML, Leal S, Morrice NA, Cross GA, Ferguson MA. Purification, cloning and characterization of a GPI inositol deacylase from Trypanosoma brucei. EMBO J. 2001;20(17):4923-34.

23. Flieger A, Neumeister B, Cianciotto NP. Characterization of the gene encoding the major secreted lysophospholipase A of Legionella pneumophila and its role in detoxification of lysophosphatidylcholine. Infect Immun. 2002;70(11):6094-106.

24. Farn JL, Strugnell RA, Hoyne PA, Michalski WP, Tennent JM. Molecular characterization of a secreted enzyme with phospholipase B activity from Moraxella bovis. J Bacteriol. 2001;183(22):6717-20.

25. Xu XW, Wu YH, Wang CS, Wang XG, Oren A, Wu M. Croceicoccus marinus gen. nov., sp. nov., a yellow-pigmented bacterium from deep-sea sediment, and emended description of the family Erythrobacteraceae. Int J Syst Evol Microbiol. 2009;59(Pt 9):2247-53.

26. Kumar NR, Nair S, Langer S, Busse HJ, Kämpfer P. Altererythrobacter indicus sp. nov., isolated from wild rice (Porteresia coarctata Tateoka). Int J Syst Evol Microbiol. 2008:58(4):839-44.

27. Kwoun Kim H, Jung YJ, Choi WC, Ryu HS, Oh TK, Lee JK. Sequence-based approach to finding functional lipases from microbial genome databases. FEMS Microbiol Lett. 2004:235(2):349-55.

28. de Pascale D, Cusano AM, Autore F, Parrilli E, di Prisco G, Marino G, Tutino ML. The cold-active Lip1 lipase from the Antarctic bacterium Pseudoalteromonas haloplanktis TAC 125 is a member of a new bacterial lipolytic enzyme family. Extremophiles. 2008;12(3):311-23.

29. Kumar S, Stecher G, Tamura K. MEGA7: molecular Evolutionary Genetics Analysis Version 7.0 for Bigger Datasets. Mol Biol Evol. 2016;33(7):1870-4.

30. Kuang S, Zheng J, Yang H, Li S, Duan S, Shen Y, Ji C, Gan J, Xu XW, Li J. Structure insight of GSDMD reveals the basis of GSDMD autoinhibition in cell pyroptosis. Proc Natl Acad Sci USA. 2017;114(40):10642-7.

31. Huo YY, Li S, Huang J, Rong Z, Wang Z, Li Z, Ji R, Kuang S, Cui HL, Li J, et al. Crystal structure of Pelagibacterium halotolerans PE8: new insight into its substrate-binding pattern. Sci Rep. 2017;7(1):4422.

32. Huang J, Huo YY, Ji R, Kuang S, Ji C, Xu XW, Li J. Structural insights of a hormone sensitive lipase homologue Est22. Sci Rep. 2016;6:28550.

33. Baker P, Ricer T, Moynihan PJ, Kitova EN, Walvoort MTC, Little DJ, Whitney JC, Dawson K, Weadge JT, Robinson H, et al. P. aeruginosa SGNH Hydrolase-Like Proteins AlgJ and AlgX have similar topology but separate and distinct roles in alginate acetylation. PLoS Pathog. 2014;10:8.

34. Lindner AB, Kim SH, Schindler DG, Eshhar Z, Tawfik DS. Esterolytic antibodies as mechanistic and structural models of hydrolases - a quantitative analysis. J Mol Biol. 2002;320(3):559-72.

35. Mohamed YM, Ghazy MA, Sayed A, Ouf A, El-Dorry H, Siam R. Isolation and characterization of a heavy metal-resistant, thermophilic esterase from a Red Sea brine pool. Sci Rep. 2013;3:3358. 
36. Chen PT, Liu CH, Chen YT, Hsu FY, Shaw JF. Isolation, expression and characterization of the thermophilic recombinant esterase from Geobacillus thermodenitrificans PS01. Appl Biochem Biotechnol. 2020. https://doi. org/10.1007/s12010-020-03225-w

37. Huang M, Parker MJ, Stubbe J. Choosing the right metal: case studies of class I ribonucleotide reductases. J Biol Chem. 2014;289(41):28104-11.

38. Duan S, Gao W, Chen Z, Li Z, Li S, Gan J, Chen X, Li J. Crystal structure of human archease, a key cofactor of tRNA splicing ligase complex. Int J Biochem Cell Biol. 2020;122:105744.

39. Rangarajan ES, Ruane KM, Proteau A, Schrag JD, Valladares R, Gonzalez CF, Gilbert M, Yakunin AF, Cygler M. Structural and enzymatic characterization of NanS (YjhS), a 9-O-Acetyl N-acetylneuraminic acid esterase from Escherichia coli O157:H7. Protein Sci. 2011;20(7):1208-19.

40. Grochulski P, Bouthillier F, Kazlauskas RJ, Serreqi AN, Schrag JD, Ziomek E, Cygler M. Analogs of reaction intermediates identify a unique substrate binding site in Candida rugosa lipase. Biochemistry. 1994;33(12):3494-500.

41. Farrokh P, Yakhchali B, Karkhane AA. Role of Q177A and K173A/Q177A substitutions in thermostability and activity of the ELBn12 lipase. Biotechnol Appl Biochem. 2018;65(2):203-11.

42. Lan D, Wang Q, Xu J, Zhou P, Yang B, Wang Y. Residue Asn277 affects the stability and substrate specificity of the SMG1 lipase from Malassezia globosa. Int J Mol Sci. 2015;16(4):7273-88.

43. Li SX, Ma Q, Lin K, Wu JJ, Wu YX, Xu JH. Essential role of Gly33 in a novel organic solvent-tolerant lipase from Serratia marcescens ECU1010 as determined by site-directed mutagenesis. Appl Biochem Biotechnol. 2014;172(6):2945-54.

44. Goomber S, Kumar A, Singh R, Kaur J. Point mutation lle137-Met Near surface conferred psychrophilic behaviour and improved catalytic efficiency to bacillus lipase of 1.4 Subfamily. Appl Biochem Biotechnol. 2016;178(4):753-65.

45. Chopra N, Kaur J. Point mutation Arg153-His at surface of Bacillus lipase contributing towards increased thermostability and ester synthesis: insight into molecular network. Mol Cell Biochem. 2018;443(1-2):159-68.

46. Tang L, Su M, Zhu L, Chi L, Zhang J, Zhou Q. Substitution of Val72 residue alters the enantioselectivity and activity of Penicillium expansum lipase. World J Microbiol Biotechnol. 2013;29(1):145-51.

47. Wahab RA, Basri M, Rahman MB, Rahman RN, Salleh AB, Leow TC. Combination of oxyanion Gln114 mutation and medium engineering to influence the enantioselectivity of thermophilic lipase from Geobacillus zalihae. Int J Mol Sci. 2012;13(9):11666-80.

48. Haney PJ, Badger JH, Buldak GL, Reich Cl, Woese CR, Olsen GJ. Thermal adaptation analyzed by comparison of protein sequences from mesophilic and extremely thermophilic Methanococcus species. Proc Natl Acad Sci USA. 1999;96(7):3578-83.

49. Haney PJ, Stees M, Konisky J. Analysis of thermal stabilizing interactions in mesophilic and thermophilic adenylate kinases from the genus Methanococcus. J Biol Chem. 1999;274(40):28453-8.

50. Querol E, Perez-Pons JA, Mozo-Villarias A. Analysis of protein conformational characteristics related to thermostability. Protein Eng. 1996;9(3):265-71.

51. Pei X, Wang J, Wu Y, Zhen X, Tang M, Wang Q, Wang A. Evidence for the participation of an extra alpha-helix at beta-subunit surface in the thermal stability of Co-type nitrile hydratase. Appl Biochem Biotechnol. 2018;102(18):7891-900

52. Choi JG, Ju YH, Yeom SJ, Oh DK. Improvement in the thermostability of D-psicose 3-epimerase from Agrobacterium tumefaciens by random and site-directed mutagenesis. Appl Environ Microbiol. 2011;77(20):7316-20.
53. Bradford MM. A rapid and sensitive method for the quantitation of microgram quantities of protein utilizing the principle of protein-dye binding. Anal Biochem. 1976;72:248-54.

54. Larkin MA, Blackshields G, Brown NP, Chenna R, McGettigan PA, McWilliam H, Valentin F, Wallace IM, Wilm A, Lopez R, et al. Clustal W and Clustal $X$ version 2.0. Bioinformatics. 2007;23(21):2947-8.

55. Wakamura K, Hirokawa K, Orita K. Dictionary of protein secondary structure: pattern recognition of hydrogen-bonded and geometrical features. Biopolymers. 1983;22(12):2577-637.

56. Robert X, Gouet P. Deciphering key features in protein structures with the new ENDscript server. Nucleic Acids Res. 2014;42(Web Server issue):W320-4.

57. Hommes FA. The integrated Michaelis-Menten equation. Arch Biochem Biophys. 1962;96:28-31.

58. Mitra S, Purkait T, Pramanik K, Maiti TK, Dey RS. Three-dimensional graphene for electrochemical detection of Cadmium in Klebsiella michiganensis to study the influence of Cadmium uptake in rice plant. Mater Sci Eng C Mater Biol Appl. 2019;103:109802.

59. Borrill AJ, Reily NE, Macpherson JV. Addressing the practicalities of anodic stripping voltammetry for heavy metal detection: a tutorial review. Analyst. 2019;144(23):6834-49.

60. Drozd M, Pietrzak M, Malinowska E. Studies on voltammetric determination of cadmium in samples containing native and digested proteins. Anal Chim Acta. 2014;819:65-70.

61. Wang Q-S, Zhang K-H, Cui Y, Wang Z-J, Pan Q-Y, Liu K, Sun B, Zhou H, Li $M-J, X u Q$, et al. Upgrade of macromolecular crystallography beamline BL17U1 at SSRF. Nucl Sci Tech. 2018;29(5):68.

62. Zhang W-Z, Tang J-C, Wang S-S, Wang Z-J, Qin W-M, He J-H. The protein complex crystallography beamline (BL19U1) at the Shanghai Synchrotron Radiation Facility. Nucl Sci Tech. 2019;30(11):170.

63. Otwinowski Z, Minor W. Processing of X-ray diffraction data collected in oscillation mode. Method Enzymol. 1997;276:307-26.

64. Murshudov GN, Skubak P, Lebedev AA, Pannu NS, Steiner RA, Nicholls RA, Winn MD, Long F, Vagin AA. REFMAC5 for the refinement of macromolecular crystal structures. Acta Crystallogr D Biol Crystallogr. 2011;67(Pt 4):355-67.

65. Murshudov GN, Vagin AA, Dodson EJ. Refinement of macromolecular structures by the maximum-likelihood method. Acta Crystallogr D Biol Crystallogr. 1997;53(Pt 3):240-55.

66. Emsley P, Cowtan K. Coot: model-building tools for molecular graphics. Acta Crystallogr D Biol Crystallogr. 2004;60(Pt 12 Pt 1):2126-32.

67. Laskowski RA, Chistyakov W, Thornton JM. PDBsum more: new summaries and analyses of the known 3D structures of proteins and nucleic acids. Nucleic Acids Res. 2005:33(Database issue):D266-8.

68. Holm L, Rosenstrom P. Dali server: conservation mapping in 3D. Nucleic Acids Res. 2010;38(Web Server issue):W545-9.

69. Holm L, Laakso LM. Dali server update. Nucleic Acids Res. 2016:44(W1):W351-5.

70. Morris GM, Huey R, Lindstrom W, Sanner MF, Belew RK, Goodsell DS, Olson AJ. AutoDock4 and AutoDockTools4: automated docking with selective receptor flexibility. J Comput Chem. 2009;30(16):2785-91.

\section{Publisher's Note}

Springer Nature remains neutral with regard to jurisdictional claims in published maps and institutional affiliations. 